\title{
HUMAN BEINGS' BIRTH, DEATH AND BEYOND
}

\author{
Y. V. Subba Rao ${ }^{* 1}$ (iD \\ ${ }^{* 1}$ University Science and Instrumentation Centre, Sri Venkateswara University, Tirupati, Andhra \\ Pradesh, India
}

DOI: https://doi.org/10.29121/granthaalayah.v8.i9.2020.1411

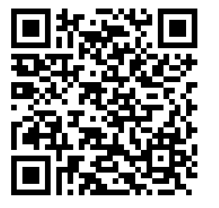

Article Type: Research Article

Article Citation: Y. V. Subba Rao. (2020). HUMAN BEINGS' BIRTH, DEATH AND BEYOND. International Journal of Research GRANTHAALAYAH, 8(9), 404-414. https://doi.org/10.29121/granthaa layah.v8.i9.2020.1411

Received Date: 06 September 2020

Accepted Date: 30 September 2020

\section{Keywords:}

Panchabhutas

Kundalini

DNA

Electromagnetism

Meteorites

Lokas

Vital Airs

Vital Fires

Pitrayāna

Devayāna

\begin{abstract}
Everything in the physical creation, including the human body, is composed of the five great natural elements called 'Panchabhutas'. These elements have originated in a particular order of 'akāsh' (ether) to the last element 'prithivi' (earth) and the birth as a human being, which is exceedingly rare, is thus born on earth with its matching fundamental frequency of the earth. As the existing literature is quite unclear regarding the human birth, death and beyond, it is attempted to show a plausible way connecting the dots of the process of birth, death, rebirth and liberation based on vibrations of frequency of mind, word, and deed. The final moments of death, step by step, where these pancha- bhutas are dissolved, in the reverse order of their formation, following the chakra system (wheels of energy) of Kundalini in a human being, similar to DNA, withdrawing the soul from the base (mulādhāra) upwards. Subtle bodies (sookshma sarira) and soul have infinite possibilities for their onward journey at the moment of death go to the dimension that corresponds to how one lived one's life on Earth. The subtle body finds its dimension and level of frequency according to merits of purity of the subtle body derived by one's life's activities rise to higher lokas for enjoying the fruits of good actions or attain liberation or to be reborn. An enlightened soul attains liberation from bondage as in the case of Swāmi Vivekānanda, and also has the freedom to be born again or not.
\end{abstract}

\section{INTRODUCTION}

Vishnu Purāna states that there is a total of 8,400,000 species classified as 200,000 species of non-mobile plants; 900,000 species of aquatic creatures; 900,000 species of amphibian and reptiles, 1,000,000 species of birds, etc.; 3,000,000 species of other creatures such as animals, etc.; 400,000 species of anthropoids (Vānaras), after which the human species (Manushya) of 200,000 varieties come into being, and Man then engages in purposeful activity to attain perfection [1].

\section{दुर्लभं मानुषं जन्म प्रार्थयते त्रिदशैरपि}

durlabham mānușham janma prārthayate tridaśhairapi

--- (Nārad Purāṇ(v28) [2]

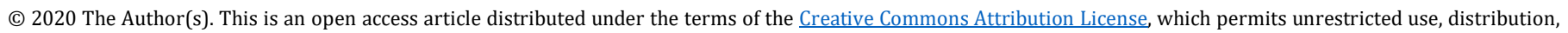
and reproduction in any medium, provided the original author and source are credited. 
Meaning: "The human form is exceedingly rare. Even the celestial gods pray to attain it." Thus, Lord Ram instructed the residents of Ayodhya:

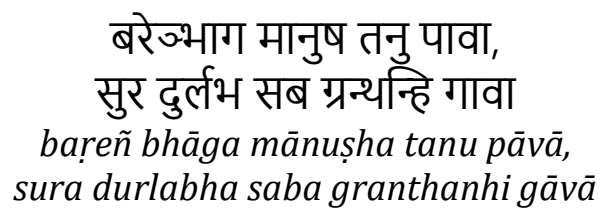

--- (Ramāyan)(v2) [3]

Meaning: "O people of Ayodhya, you all are extremely fortunate to have been bestowed a human birth, which is exceedingly rare and is desired even by the residents of heaven." When the celestial beings long for a human birth, then why should we humans seek promotion to the celestial abodes? Rather, we should aim for God-realization by engaging in devotion to the Supreme Lord.

It fascinates one and all and curious to know what happens at the moment of death? what happens after death? and Is there life beyond? Man is a Microcosm of the Macrocosm, the Universe. The entire cosmos is an interplay of the energies of the five great elements. It is said that from the heavenly bodies we get ether, and from ether we get air, from these two we get fire, from these three we get water, and from these four we get earth. These are said to be the five elements which are found in every living being though, it may be, in different proportions [4].

All living things on the face of the earth, the earth itself, and the heavens themselves, are said to possess five kinds of vital airs called Prāna, Apāna, Vyāna, Udhāna, and Samāna. They are said to mean respectively, the air in the heart that ascends, the air in the anus that descends, the air in all parts of the body that circulates, the air in the throat that keeps down the food and drink, and the air in the navel that carries the finer portions of food and drink to different parts of the body. All living things, the earth and the heavens also have, it is said, three kinds of vital fires, and through the action and inter-action of these vital airs and vital fires result the several seasons and the different conditions of creation, preservation and destruction. The five natural elements, the five vital airs and the three vital fires give rise to Vāta, Pitta and Kapha.

Ayurveda identifies three basic types of energy or functional principles that are present in everyone and everything. They are Vāta, pitta and kapha which are combinations and permutations of these five elements that manifest as patterns present in all creation. In the physical body, vāta is the subtle energy of movement, pitta the energy of digestion and metabolism, and kapha the energy composed of Space and Air. It governs breathing, blinking, muscle and tissue movement, pulsation of the heart, and all movements in the cytoplasm and cell membranes. In balance, $v \bar{a} t a$ promotes creativity and flexibility. Out of balance, vāta produces fear and anxiety. Pitta expresses as the body's metabolic system - made up of Fire and Water. It governs digestion, absorption, assimilation, nutrition, metabolism and body temperature. In balance, pitta promotes understanding and intelligence. Out of balance, pitta arouses anger, hatred and jealousy. Kapha is the energy that forms the body's structure - bones, muscles, tendons - and provides the "glue" that holds the cells together, formed from Earth and Water. Kapha supplies the water for all bodily parts and systems. It lubricates joints, moisturizes the skin, and maintains immunity. In balance, kapha is expressed as love, calmness and forgiveness. Out of balance, it leads to attachment, greed and envy. These three when in balance give rise to Sattva guna (mode of goodness) while out of balance, they give rise to two modes of nature, namely, Rajo guna (Mode of passion) and Tamo guna (Mode of ignorance) in human beings. Every individual is a unique mix of these three gunas, thus, giving rise to infinite dimensions of vibrations with different permutations and combinations to which the two bodies, namely the physical body and the subtle body and the souls are tied. Based on the frequency fundamentally matching with the earth's frequency arising out of Tamo guna and Rajo guna with the earth's frequency (Schuman's Resonance), the subtle body with the soul cannot travel beyond the earth after death.

\footnotetext{
"Time creates and time alone kills. This is the inevitable law of time,"$$
\text { जातस्य हि ध्रुवो मृत्युर्ध्रुवं जन्म मृतस्य च। }
$$$$
\text { तस्मादपरिहार्येऽर्थे न त्वं शोचितुमर्हसि || 27|| }
$$$$
\text { jātasya hi dhruvo mrityur dhruvam janma mritasya cha }
$$$$
\text { tasmād aparihārye 'rthe na tvam śhochitum arhas } i
$$

--- Bhagavat Gita Ch.2, Text 27 [5] 


\section{Y. V. Subba Rao}

Meaning: Death is certain for one who has been born, and rebirth is inevitable for one who has died. Therefore, you should not lament over the inevitable.

\section{THE THREE KINDS OF KARMA}

Karma is of three kinds, viz., Sanchita (accumulated works), Prarabdha (fructifying works) and Kriyamana or Agami (current works). Sanchita is all the accumulated Karmas of the past. Part of it is seen in the character of man, in his tendencies and aptitudes, capacities, inclinations and desires, etc. Tendencies come from this. Prarabdha is that portion of the past Karma which is responsible for the present body. That portion of the Sanchita Karma which influences human life in the present incarnation is called Prarabdha. It is one's destiny to be worked out in this life which results from the actions performed and desires craved in the past lives. It is ripe for reaping. It cannot be avoided or changed. It is only exhausted by being experienced. You pay your past debts. Prarabdha Karma is that which has begun and is actually bearing fruit. It is selected out of the mass of the Sanchita Karma. Kriyamana is that Karma which is now being made for the future. It is also called Agami or Vartamana.

In Vedantic literature, there is a beautiful analogy. The bowman has already sent an arrow and it has left his hands. He cannot recall it. He is about to shoot another arrow. The bundle of arrows in the quiver on his back is the Sanchita; the arrow he has shot is Prarabdha; and the arrow which he is about to shoot from his bow is Agami. Of these, he has perfect control over the Sanchita and the Agami, but he must surely work out his Prarabdha. The past which has begun to take effect he has to experience.

\section{TWO PATHS OF JOURNEY OF THE SUBTLE BODY AND THE SOUL (PITRAYĀNA AND DEVAYĀNA)}

There are two paths for the journey of the subtle body and the soul. One of which leads to liberation and the other leads to rebirth. Liberation lies in transcending the three gunas, i.e., three modes of material nature. Those who know the Supreme Brahman, and who depart from this world, during the six months of the sun's northern course, the bright fortnight of the moon, and the bright part of the day, attain the supreme destination. The practitioners of Vedic rituals, who pass away during the six months of the sun's southern course, the dark fortnight of the moon, the time of smoke, the night, attain the celestial abodes. After enjoying celestial pleasures, they again return to the earth. These two, bright and dark paths, always exist in this world. The way of light leads to liberation and the way of darkness leads to rebirth [6].

$$
\begin{aligned}
& \text { शुक्लकृष्णे गती ह्येते जगतः शाश्वते मते । } \\
& \text { एकया यात्यनावृत्तिमन्ययावर्तते पुनः ॥८-२६॥ } \\
& \text { śhukla - krișhṇe gati hy ete jagatah śhāśhvate mate। } \\
& \text { ekayã yãti anāvrittim anyayãvartate punah॥ }
\end{aligned}
$$

--- Bhagavad Gita Ch.8 - Verse26 [7]

Meaning: These two paths of the world, the bright and the dark, are considered to be eternal; by one, one returns not, and by the other, one returns.

One of the two paths lead to liberation (Devayāna) and the other leads to rebirth (Pitrayāna). Those who know the Supreme Brahman, and who depart from this world, during the six months of the sun's northern course, the bright fortnight of the moon, and the bright part of the day, attain the supreme destination. The practitioners of Vedic rituals, who pass away during the six months of the sun's southern course, the dark fortnight of the moon, the time of smoke, the night, attain the celestial abodes. After enjoying celestial pleasures, they again return to the earth. These two, bright and dark paths, always exist in this world. The way of light leads to liberation and the way of darkness leads to rebirth.

It is tradition among Indians that those who perform meritorious deeds while living on the Earth go to Heaven. One who is promoted to those higher planetary systems enjoys a longer duration of life and better facilities for sense enjoyment, yet one is not allowed to stay there forever. One is again sent back to this earthly planet upon finishing 
the resultant fruits of pious activities and reborn. It has also been witnessed that at the departure of great souls, a bright star is seen shooting up towards the heavens.

\section{THE FOURTEEN LOKAS OR MULTIVERSE}

There exist fourteen lower lokas, seven below and seven upper lokas including the earth in the celestial sphere (Figure 1). The Earth resonates at a frequency of $7.83 \mathrm{~Hz}$. Birth as a human being is unique in that all human beings resonate fundamentally with the earth's frequency whereas all other species living on earth resonate harmonically. The frequency of other lokas vary with their respective heights from the earth and one day in each loka varies several earth years with their position above the earth. The subtle body and the soul pick up all the meritorious actions or deeds performed by the individual during his life with the rise in their frequency level accordingly [8] (Figure 1).

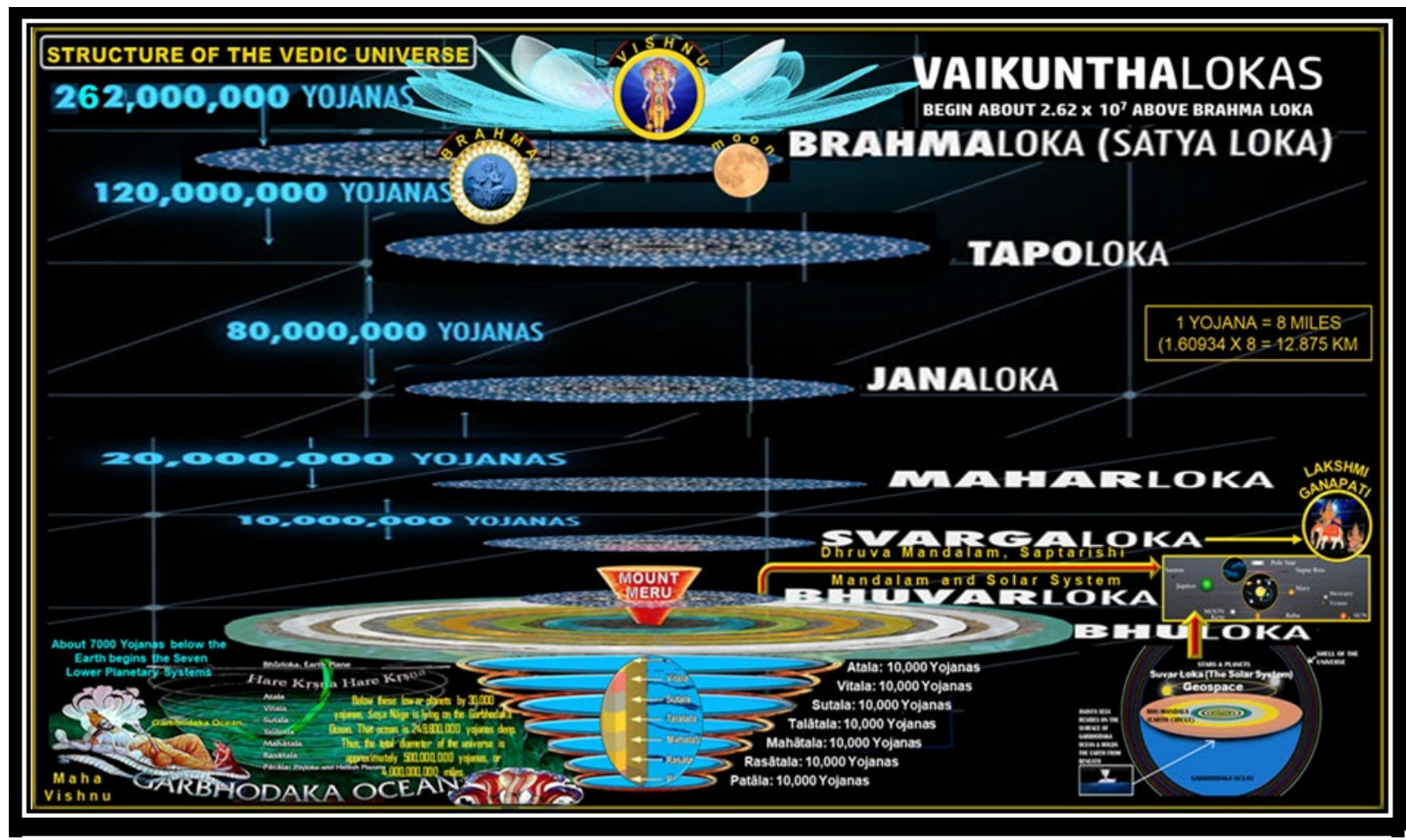

Figure 1: The fourteen Lokas (Universes) (Seven Lower and Seven Upper Lokas from Bhooloka to Brahmaloka

\section{METEORITES}

Varāhamihira, Indian Astrologer and Astronomer par excellence of the 5th century, states that the meteorites are nothing but the forms of those who fall down to be reborn after having enjoyed the fruits of their meritorious deeds in Heaven. They are divided into five categories viz. Ignescent Balls, Meteors, Thunder-bolts, Lightning and Shooting Stars (Comets). The same can be found fortified in Bhagavat Gita.

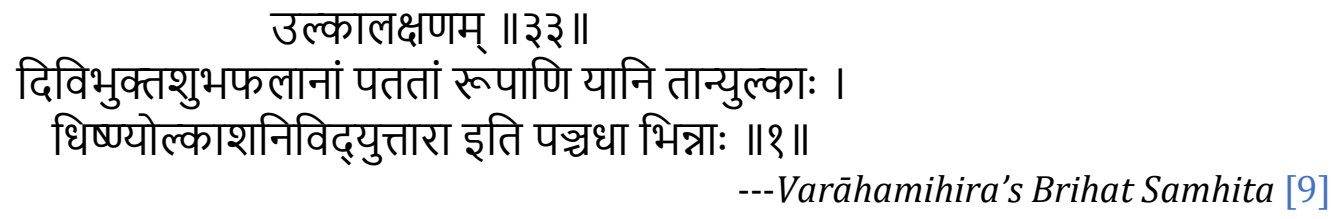

Meaning: The forms of those who fall down after having enjoyed unalloyed happiness in Heaven are called Ulkas or Meteors which are divided into five kinds, viz., ignescent balls, meteors, thunder-bolt, lightning and shooting stars. 


\section{ते तं भुक्त्वा स्वर्गलोक विशालं क्षीणे पुणये मर्त्यलोकं विशन्ति । \\ एवं त्रयीधर्ममनुप्रपनना गतागतं कामकामा लभन्ते ॥९-२१॥}

te tam bhuktvã svarga-lokam visãlam; ksine punye martya-lokam visanti levam trayi-dharmam anuprapannã; gatãgatam kãma-kãma labhante ॥

--- Vide the Bhagavat Gita: Chapter 9, Text 21 [10]

Meaning: When they have thus enjoyed heavenly sense pleasure, they return to this mortal planet again. Thus, through the Vedic principles, they achieve only flickering happiness.

\section{HUMAN DNA AND KUNDALINI}

Both Human DNA and Kundalini have a similar structure. Kundalini is a Sanskrit word meaning either "coiled up" or "coiling like a snake." The coiled snake stands for the helical form of the DNA There are 7 Chakras or the seven wheels of energy in the astral body. Six of them are found along the spine, and the seventh is located at the crown of the head. They represent colours of the light spectrum (VIBGYOR) (Figures 2 and 3) [11].

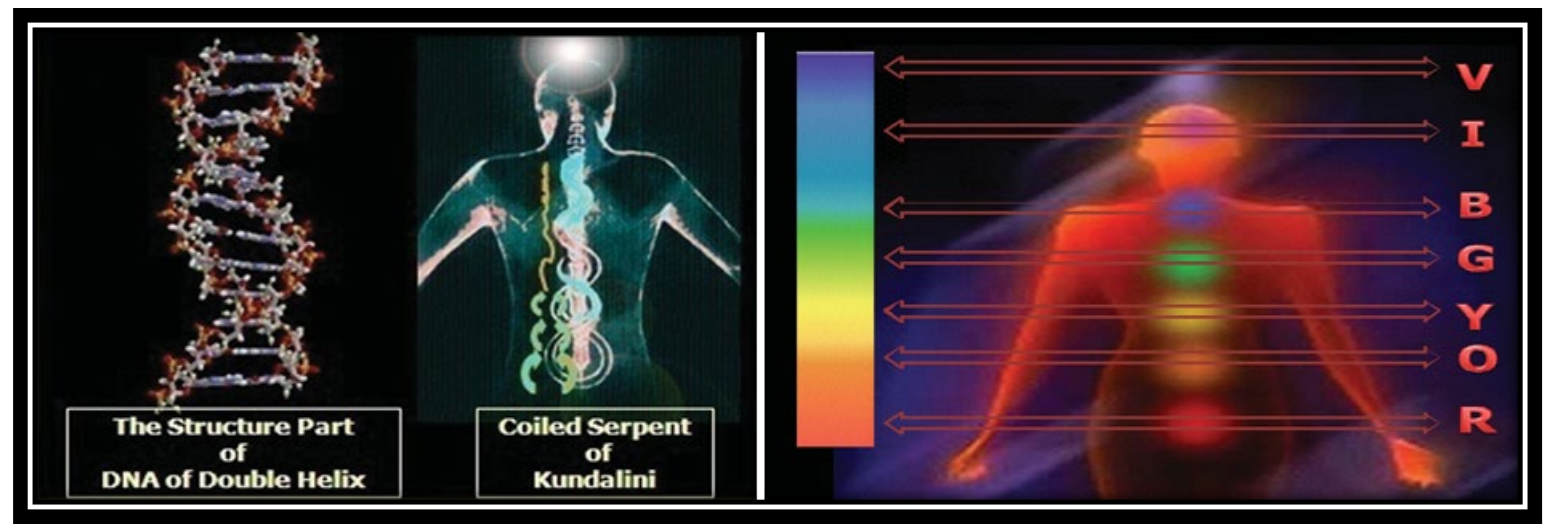

Figures 2 and 3: Kundalini is akin to DNA; 7 Chakras of Kundalani with VIBGYOR colours of Electromagnetic Spectrum

\section{PHYSICAL AND SPIRITUAL EVOLUTION AND HUMAN DNA}

Chakras are powerful energy centres in the body. Although they are invisible to the eye, these wheels of spiritual energy balance the body and spirit. The Chakras store dynamic energy known to the Yogis in India as Kundalini. The three lower Chakras correlate to basic primary needs, those of survival, procreation, and will. The four higher Chakras correlate to the psychological make-up and represent higher spiritual qualities such as love, compassion, and understanding. The Chakras store dynamic energy known to the Yogis in India as Kundalini. The colours (VIBGYOR) of the three lower Chakras are Red, Orange, and Yellow; and the four upper Chakras are Green, Blue, Indigo, and Violet, respectively. Six of them are found along the spine, and the seventh is located at the crown of the head. One who raises the Kundalini to the crown of the head through meditation attains liberation, says Yoga Sāstra. The crown Chakra is of violet colour. The colours of chakras are akin to the electromagnetic spectrum.

The wavelength of a sinusoidal waveform traveling at constant speed " $v$ " is given by $v=\lambda f$. Raising the Kundalini to the crown of the head "Sahasrära" Chakra of violet colour tunes the body and mind to the highest level of frequency and shortest wavelength, enables to see matter of several times below the subatomic level with a steady state of mind.

When Kundalini rises to the pineal gland (6 $6^{\text {th }}$ Chakra) and then through "Cerebrum" above the body to "Sahasrāra" Chakra (the seventh Chakra), the individual attains liberation of soul from bondage, that is, Moksha. The sequence of seven Chakras of Kundalini is VIBGYOR, the electromagnetic spectrum. Sahasrāra Chakra is of violet colour.

The wavelength of a sinusoidal waveform traveling at constant speed " $v$ " is given by $v=\lambda f$. Raising the Kundalini to the crown of the head "Sahasrāra" Chakra of violet color tunes the body and mind to the highest level of frequency 
" $f$ " and shortest wavelength " $\chi$ " enables to see matter of several times below the subatomic level without any lens medium and with a steady state of mind.

$v=\lambda f$.

" $v$ " can reach a maximum value of speed of light and limited to " $c$ " (the velocity of light) in $E$ (energy) $=m c^{2}$

and as the frequency increases with the decreasing wavelength results in enormous energy in the enlightened individual when he attains liberation (Figure 4) [12].

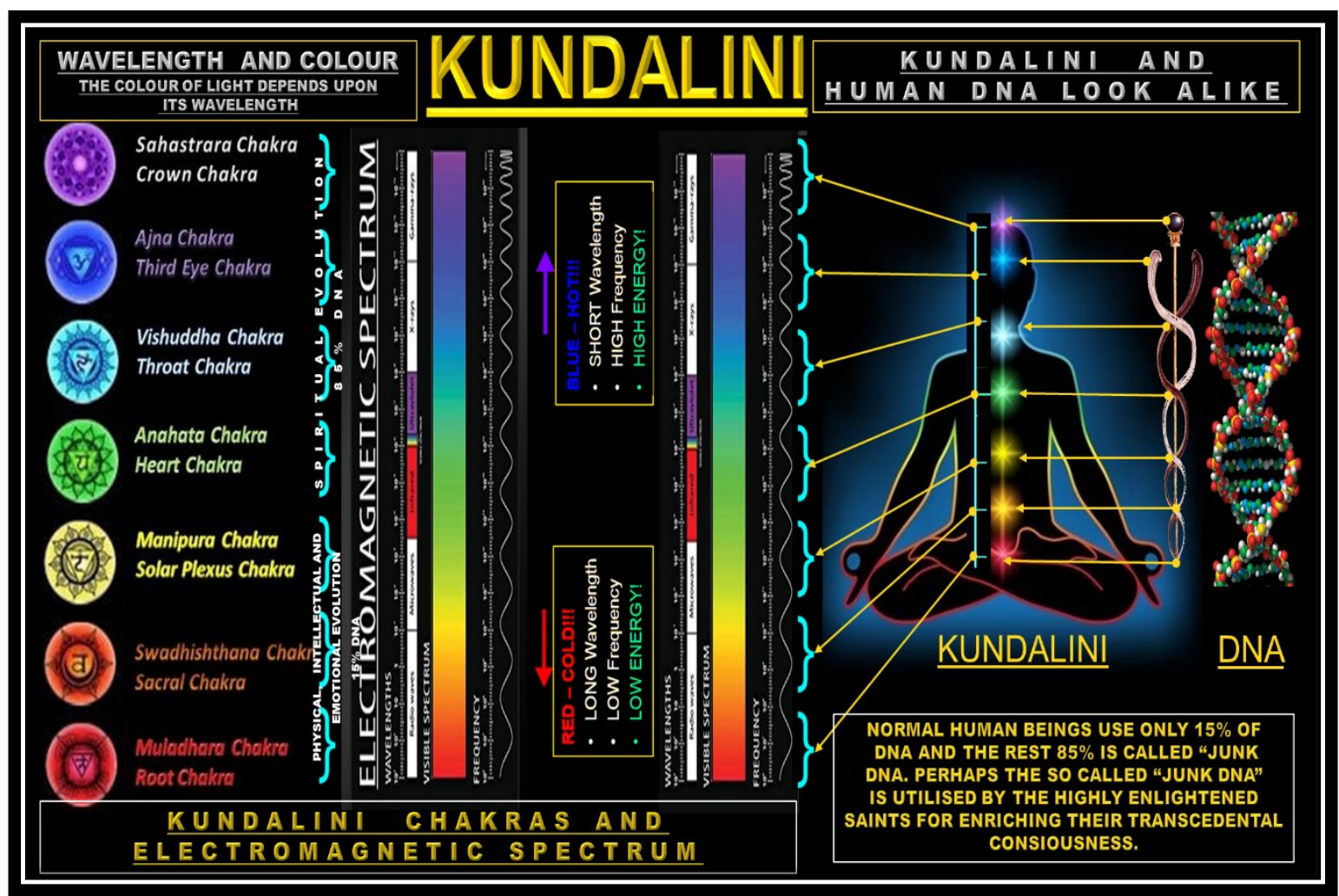

Figure 4: Chakra Colours, Electromagnetic Spectrum, DNA and Evolution

Our life experiences shape with the first three elements and together with our DNA, we become defined. The physical body records the vibrations of evil deeds while the subtle body and soul record the meritorious deeds. Perhaps, only $15 \%$ of DNA is utilized by almost all of us for the makeup of first three elements, in other words, utilization of the three lower Chakras of Kundalini. As has been stated elsewhere, the dormant force of Kundalini seems to account for $85 \%$ of unused DNA. One in a billion is completely made up of the $4^{\text {th }}$ element - Spiritual which may perhaps be the case of highly enlightened souls plausibly that require total utilization of $100 \%$ DNA. DNA can adopt different alternative structures.

As has been said elsewhere herein, the various stages of journey through which the subtle body and the soul experience in case of Pitrayāna and Devayāna are explained in the following two diagrams for brevity (Figures 5 and 6). One of the two paths lead to liberation (Devayāna) of those who know the Supreme Brahman, and who depart from this world and those who perform meritorious deeds enjoy the fruits of their actions and return to earth to be reborn (rebirth) (Pitrayāna) [13]. 


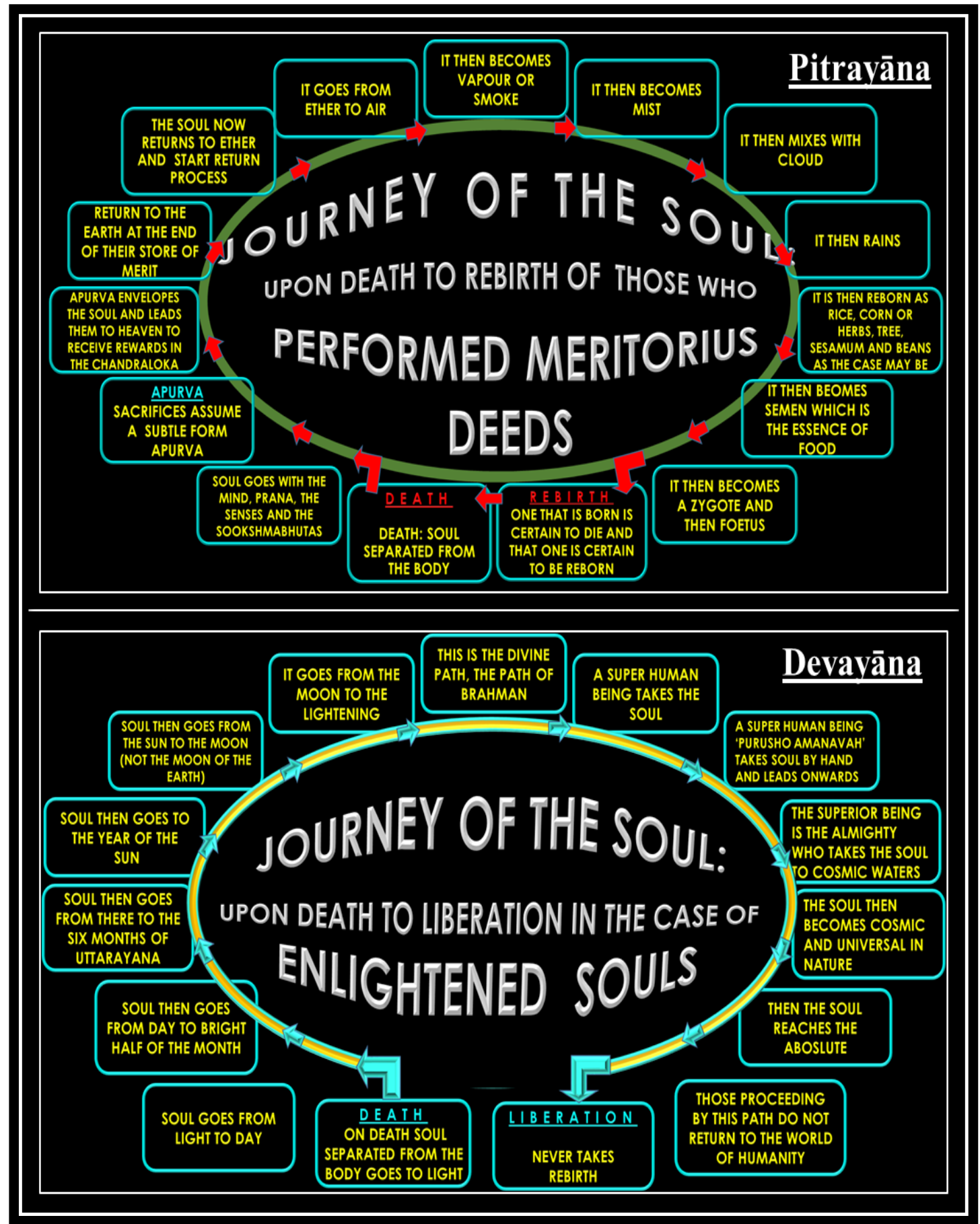

Figures 5 and 6: Stages of Journey of Subtle body and Soul in the two Paths

मनुष्याणां सहस्रेषु कश्चिद्यतति सिद्धये ।

यततामपि सिद्धानां कश्चिन्मां वेत्ति तत्त्वतः ॥७-३॥

manusyãnãm sahasresu kascid yatati siddhaye 1

yatatãm api siddhãnãm kascin mam vetti tattvatah 11

---- Bhagavat Gita Chapter 7 - Text 3 [14]

Meaning: Among thousands of men one perchance struggles for perfection, only one perchance becomes perfect, and even amongst those that are perfect, one perchance knows ME in reality. 


\section{SWĀMY VIVEKĀNANDA}

It is said that $S w a \bar{a} m i$ Vivekananda was seen intently studying the almanac from a few days prior to his demise. He even pointed the spot for his cremation and told several people that he would not live to be forty. The Swāmi left his mundane body on his own volition in 1902. Vivekananda died at 10 min past 9 pm on July 4, 1902, while meditating. A little blood in the Swāmi's nostrils, his mouth, and in his eyes, was noticed which was due to rupture of the blood vessel in the brain according to doctors. According to his disciples, it was due to the escape of his soul through Brahmarandhra, the aperture in the crown of the head, which must have been pierced when he attained Mahāsamādhi. Thus, the end of Swāmi is unique and came on his own volition [15].

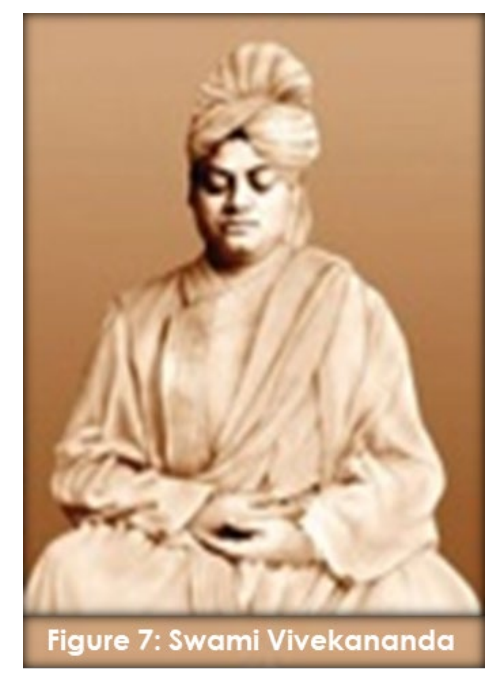

\section{INSIGHTS ON THE END OF LIFE}

The raison d'etre of human birth is liberation from bondage. Man appears to be practically a slave to the efforts of his past karma, but he is a free agent with regard to fresh and independent deeds. If these fresh and independent deeds resulting from his free will are in any manner directed to thwart the effects of his past karma, he seems to be doomed to failure. The acuteness of his failure seems to be proportionate to the disparity between the forces of fate and resisting will-power. On the other hand, if the fresh and the independent deeds are directed into neutral fields and neutral periods, the success appears to be proportionate to the force of the will and the effort put forward. While accepting the negative effects in life due to past karma, one must work for a positivity further in life. Negativity is natural whereas positivity requires effort. It is through this free will, with which man responds to fate by deed and thought, that he stores up the good or bad karma for the life to come, in other words, elevates himself to obtain liberation from death or brings himself down from life to life encircling in the endless death-birth cycle. Today's freewill is tomorrow's destiny. While action is always present, the occurrence of reaction depends on the individual's motive and the action itself. It is this view of a harmonious combination of fate and free will that seem to account for the baffling inequities in life, while affording an answer to the perennial subject of Fate Versus Free Will [16].

The chakra system of a human being defines the withdrawing of the soul from the base upwards at the moment of termination of the mundane existence. The First element 'earth' is withdrawn from the Mulädhära chakra when the element 'Earth' is dissolved and moves upward to the Svädhishthāna chakra, when it is converted into the second element 'water'. The hands and feet of the dying person will suddenly become cold. The water element moves upward to the Manipura chakra when the water element is converted into the third element 'Fire'. Likewise, the third element 'Fire' moves gradually further upward to the two chakra Anahata chakra and Visuddha chakra, where this 'Air' element produces a low gargling sound with the dissolution of the 'Ether' element. Thus, the five natural elements "Panchabhutas" are dissolved leaving the body 'dead' with the exit of the soul through any one of the three vents, namely, mouth, eyes or ears. In the case of saints, it exits through 'Brahmarandhra' the back of the head at the place of the pony tail known as 'sikham' and they attain liberation.

"A Saint has always a Past and a Sinner has a Future"

International Journal of Research -GRANTHAALAYAH 


\section{Y. V. Subba Rao}

With the death, the "Panchabhutas" dissolve into their respective pools. The physical body perishes on the funeral pyre, the soul together with the subtle body with all the vibrations and reactions of individuals' actions of meritorious nature set sail to a loka that matches with its frequency. The interval between death and rebirth depends on the duration of equivalence of one day in the loka where the subtle body stations equivalent to the number of the earth years (Figure 8).

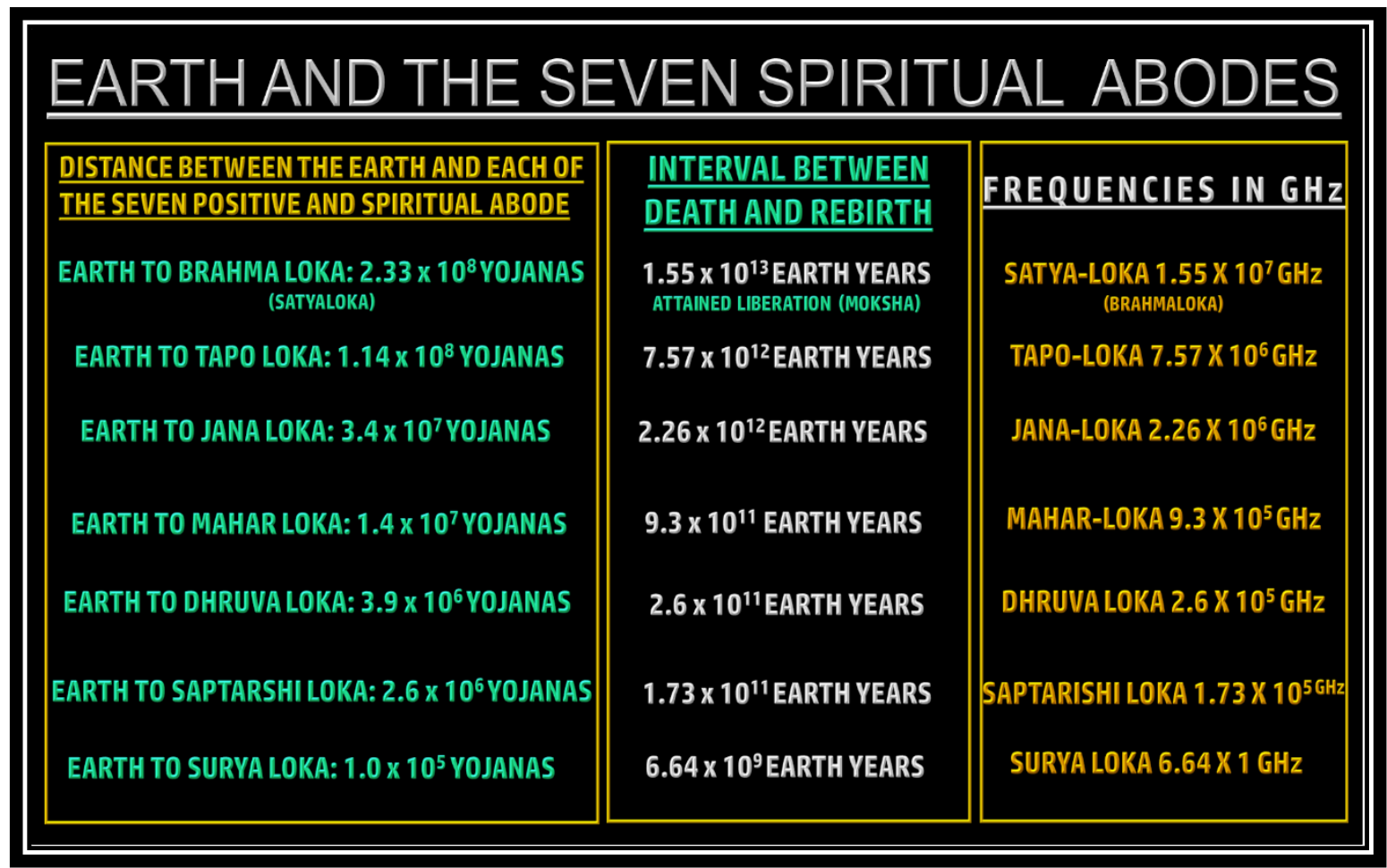

Figure 8: The Seven Urdhva Lokas (Upper Worlds) Heights and Equivalent Earth Years

\section{CONCLUSION}

Life originates in Space according to Veda. Even souls evolve and finally obtain liberation. NASA found that life building blocks of DNA are available as ready-made kits in space and delivered to the Earth by meteorites. European Planetary Science Congress suggested that the microorganisms from the distant planets might have been the sprouts of life on this planet. The building blocks of life remained intact despite the tremendous shock wave and other violent conditions after collision. Astronomy states that interplanetary transportation of meteorites is equally true. This corroborates with the Vedas, Vedānga, Bhagavat Gita, and Hindu Mythology. Young Dhruva, the legend, became a star known as "Polaris."

The raison d'etre of human birth is liberation from bondage. Man appears to be practically a slave to the efforts of his past karma, but he is a free agent with regard to fresh and independent deeds. If these fresh and independent deeds resulting from his free will are in any manner directed to thwart the effects of his past karma, he seems to be doomed to failure. The acuteness of his failure seems to be proportionate to the disparity between the forces of fate and resisting will-power. On the other hand, if the fresh and the independent deeds are directed into neutral fields and neutral periods, the success appears to be proportionate to the force of the will and the effort put forward. It is through this free will, with which man responds to fate by deed and thought, that he stores up the good or bad karma for the life to come, in other words, elevates himself to obtain liberation from death or brings himself down from life to life encircling in the endless death-birth cycle. Today's freewill is tomorrow's destiny. While action is always present, the occurrence of reaction depends on the individual's motive and the action itself. It is this view of a harmonious combination of fate and free will that seems to account for the baffling inequities in life, while affording an answer to the perennial subject of Fate Versus Free Will [17]. 
The chakra system of a human being defines the withdrawing of the soul from the base upwards at the moment of termination of the mundane existence. The First element 'earth' is withdrawn from the Mulädhära chakra when the element 'Earth' is dissolved and moves upward to the Svādhishthāna chakra, when it is converted into the second element 'water'. The hands and feet of the dying person will suddenly become cold. The water element moves upward to the Manipura chakra when the water element is converted into the third element 'Fire'. Likewise, the third element 'Fire' moves gradually further upward to the two chakra Anahata chakra and Visuddha chakra, where this 'Air' element produces a low gargling sound with the dissolution of the 'Ether' element. Thus, the five natural elements "Panchabhutas" are dissolved leaving the body 'dead' with the exit of the soul through any one of the three vents, namely, mouth, eyes or ears. In the case of saints, it exits through 'Brahmarandhra' the back of the head at the place of the pony tail known as 'sikham' and they attain liberation.

"A Saint has a Past and a Sinner has a Future"

With the death, the "Panchabhutas" dissolve into their respective pools. The five elements of body plausibly record all vibrations set by his evil actions and the physical body perishes on the funeral pyre, the soul together with the subtle body with all the vibrations of meritorious actions and reactions of individuals' set sail to a loka of a particular height that matches with its frequency. The interval between death and rebirth depends on the duration of equivalence of one day in the loka where the subtle body stations equivalent to the number of the earth years based on the height of the loka above the Earth.

\section{SOURCES OF FUNDING}

This research received no specific grant from any funding agency in the public, commercial, or not-for-profit sectors.

\section{CONFLICT OF INTEREST}

The author have declared that no competing interests exist.

\section{ACKNOWLEDGMENT}

I profusely thank my son, Prof. Y. V. Ramana Rao, M. Tech., Ph. D., Department of Electronics and Communication, Engineering, College of Engineering, Anna University, Chennai, India, for his critical comments in improving this research paper.

\section{REFERENCES}

[1] B. K. Chaturvedi (2015), Vishnu Puran, Diamond Publishers, New Delhi, eISBN 97-893-5083-749-8

[2] Sankshipt Narad Puran (Hindi), Geeta Press Gorakhpur; 1 edition

[3] ASIN: B01M3Z1JQVwww.valmikiramayan.net

[4] Vedic Paradigm

[5] Bhagavat Gita Large Print Edition Sanskrit. The Devanagari text “Sanskrit 2003”, Verse 27. Ch. 2; 2003.

[6] Venkata Subba Rao Yeragudipati (2017), Live Vedanta: Prevent Population Explosion, Lambert Academic Publications, West Germany, ISBN: 978-3-330-32022-2

[7] Bhagavat Gita Large Print Edition Sanskrit. The Devanagari text “Sanskrit 2003”, Verse 26. Ch. 8; 2003.

[8] decodehindumythology.blogspot.com/.../lokas-planets-of-advanced-alie...

[9] Bhat MR. Signs of Meteors Varahamihira's Brihat Samhita. English Translation. Vol. 1, Ch. 33. Delhi: Motilal Banarsidas Publishers Pvt. Ltd.; 1997. p. 307.

[10] Bhagavat Gita Large Print Edition Sanskrit. The Devanagari text “Sanskrit 2003”, Verse 21. Ch. 9; 2003.

[11] Y.V. Subba Rao. (2020). “FATE AND FREEWILL.” International Journal of Research - Granthaalayah, 8(3), 147155. https://doi.org/10.5281/zenodo.3733081. 
[12] Subba Rao YV. Role of junk DNA in the liberation of soul. Int J Yoga - Philosop Psychol Parapsychol 2015; 3:23-30.

[13] Venkata Subba Rao Yeragudipati (2017), Vedic Paradigm, Lambert Academic Publications, West Germany, ISBN: 978-620-2-00775-7

[14] Bhagavat Gita Large Print Edition Sanskrit. The Devanagari text "Sanskrit 2003", Verse 3. Ch. 7; 2003.

[15] Swami Vivekananda, life and teachings-belur.www.belurmath.org/swamivivekananda.htm

[16] Rao, Y.H. and Rao, Y.V.S. (2004), "Astrology on the Moving Zodiac - The One System for the East and the West", Author's Publication. ISBN 81-7525-939-66 Review: (Extract from 'ASTROLOGY', The Astrologers' Quarterly, England, Vol.56, No.1, Spring 1982)

[17] Rao, Y.H. and Rao, Y.V.S. (2004), "Astrology on the Moving Zodiac - The One System for the East and the West", Author's Publication. ISBN 81-7525-939-66 Review: (Extract from 'ASTROLOGY', The Astrologers' Quarterly, England, Vol.56, No.1, Spring 1982)

\section{BIOGRAPHY}

Venkata Subba Rao Yeragudipati, Ph.D., FIE., C. Eng. (I) was born in 1938. He is a Chartered Mining Engineer, Govt. of India Certified Mines Manager, Certified Mines Surveyor, Astronomer, Author and Astrologer. He was a faculty member of Mining Engineering Department of Osmania University, Hyderabad and later in Geology Department of S. V. University, Tirupati, India. After retirement, as Executive Engineer, he served as Visiting Professor of Jyotish (Astronomy), Central Sanskrit University, Tirupati. He is the author of several books on Veda-Sciences published by Lambert Academic Publications, West Germany and has several research papers to his credit published in National Journals and International Journals of UK and USA. He is a Member

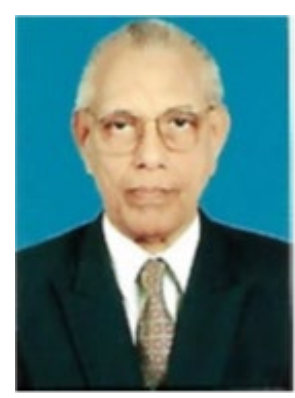
of several professional bodies. 